tologia, no entanto é frequentemente assintomática. O diagnóstico é clínico e imagiológico, mas a confirmação exige biópsia óssea. Não requer tratamento, devendo ser periodicamente avaliada com exames de imagem. A manutenção da higiene oral rigorosa e a evicção da instrumentação é fundamental pelo risco aumentado de osteomielite cuja terapêutica, além de antibioterapia prolongada, poderá incluir sequestrectomias com sequelas funcionais e estéticas.

http://doi.org/10.24873/j.rpemd.2022.01.891

\section{\#034 Cavldade oral: Local de apresentação de linfoma de células do manto}

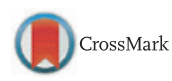

Cristina Barros*, Paula Maria Leite, Patrícia Caixeirinho, Yashad Mussá, António Figueiredo, Maria do Céu Machado

CHULC - Serviço de Estomatologia do Hospital de São José, CHULC - Serviço de Anatomia Patológica do Hospital Curry Cabral

Introdução: O linfoma de células do manto (LCM) é um subtipo de linfoma não-Hodgkin (LNH) de células B maduras com comportamento agressivo. O envolvimento ganglionar constitui a forma primária de apresentação verificando-se, em estadios avançados, atingimento extra-ganglionar, no qual a cavidade oral é um local raro de apresentação. Descrição do caso clínico: Doente do sexo feminino, caucasiana, 79 anos, sem antecedentes médicos relevantes, observada no serviço de Estomatologia. O exame intra-oral destacou, à palpação, lesão submucosa jugal direita, indolor, na região do ducto de Stenon, com cerca de $30 \mathrm{~mm}$ de maior diâmetro, arredondada, móvel e de consistência dura-elástica. O exame extra-oral revelou adenomegalias cervicais bilaterais. Sem febre, astenia ou perda ponderal. Foi realizado estudo analítico, tomografia computorizada (TC) da cabeça e pescoço e biópsia excisional de gânglio cervical. O estudo analítico não demonstrou alterações. A TC confirmou lesão ocupante de espaço com $14 \mathrm{~mm}$ de diâmetro, localizada na mucosa jugal direita, com progressão à profundidade, sem envolvimento muscular ou ósseo, esferoide, contorno regular e adenomegalias cervicais (níveis Ib, IIa, III e IV) com características suspeitas de doença linfoproliferativa. O estudo histopatológico e imunohistoquímico confirmou o diagnóstico de LCM (CD5, CD20, Ciclina D1). A doente foi encaminhada para o serviço de Hematologia Clínica para orientação terapêutica. Discussão e conclusões: O LCM constitui cerca de $3-10 \%$ dos LNH, sendo mais prevalente em indivíduos de meia-idade (69-70 anos) do sexo masculino e tem tipicamente a translocação $\mathrm{t}(11 ; 14)$ (q13; q32). A sua apresentação na cavidade oral é rara (cerca de $2 \%$ dos casos) e os locais comumente afetados são por ordem de frequência o palato, a língua, a gengiva, o pavimento e as glândulas salivares. Geralmente, ocorre sob a forma de massa indolor, não ulcerada, uni/bilateral ou multifocal. O diagnóstico baseia-se na avaliação histopatológica, imunohistoquímica e citogenética. O tratamento varia de acordo com o estadio da doença e pode incluir terapêutica dirigida, quimio/imuno/imunoquimioterapia, radioterapia e transplante alogénico de células estaminais, sendo a resposta limitada com sobrevida média de 4-5 anos. Tratando-se de uma doença com mau prognóstico, a realização de exame oral e cervical no exame objetivo de rotina é fundamental no estabelecimento do diagnóstico e melhoria do prognóstico.

http://doi.org/10.24873/j.rpemd.2022.01.892

\#035 Displasia ectodérmica hipohidrótica - A propósito de um caso clínico

Ana Teresa Coelho*, Leonor Cruz e Silva, Beatriz Mota, Filipa Contente, Nuno Zeferino Santos, Francisco Salvado

Centro Hospitalar Universitário de Lisboa Norte, CIIEM

Introdução: A displasia ectodérmica constitui um grupo heterogéneo de condições congénitas raras que afetam o desenvolvimento de pelo menos duas estruturas derivadas da ectoderme, nomeadamente, pele, cabelo, dentes e glândulas écrinas. A displasia ectodérmica hipohidrótica ligada ao cromossoma X é a forma mais comum de displasia ectodérmica. Deve-se a mutações no gene que codifica a proteína transmembranar Ectodisplasina 1, perturbando a interação entre as células epiteliais da ectoderme e o mesênquima durante o desenvolvimento embrionário. Clinicamente carateriza-se por capacidade reduzida de sudorese (hipohidrose), rarefação pilosa (hipotricose) e redução do número de dentes (hipodontia). Pode associar-se a xerose, xeroftalmia, infeções respiratórias recorrentes e dismorfia facial. As manifestações dentárias incluem alterações em número, desde hipodontia até à ausência de todos os dentes permanentes ou decíduos, e também da morfologia da coroa dentária (conicidade, taurodontia), condicionando a mastigação e fala, além do compromisso estético. Descrição do caso clínico: Sexo masculino, caucasiano, 11 anos, com diagnóstico de displasia ectodérmica hipohidrótica ligada ao cromossoma X e comorbilidades de eczema atópico e asma. Seguido na Clínica Universitária de Estomatologia do Centro Hospitalar Universitário Lisboa Norte desde os 6 anos, altura em que apresentava hipotricose generalizada, proeminência frontal, gengivite associada a placa bacteriana, desmineralização de esmalte e dentes 51, 55, 16, 61, 65 e 26 erupcionados, com conicidade das coroas dos incisivos centrais e um aumento da coroa clínica dos primeiros molares definitivos. Na ortopantomografia observava-se atrofia mandibular, dentes $13,21,23,31,33,36$ e 46 em desenvolvimento, com ausência de outros gérmens dentários. Mantém seguimento regular na consulta de Estomatologia com controlo da placa bacteriana e reabilitação dentária com prótese parcial removível superior e inferior. Discussão e conclusões: Hipodontia e alteração morfológica dentária podem ser indicadores de displasia ectodérmica hipohidrótica, principalmente em doentes do sexo masculino. A reabilitação protética é aconselhada, optando-se por prótese removível até aos 18 anos. O seguimento regular em idade pediátrica de doentes com displasia ectodérmica hipohidrótica é de elevada importância dada a necessidade de ajustes e substituição periódica das próteses dentárias de forma a acompanhar o desenvolvimento craniofacial.

http://doi.org/10.24873/j.rpemd.2022.01.893 